Research Article

\title{
Creatinine Clearance Levels are associated with the Incidence of Preeclampsia
}

\section{Nilai Creatinine Clearance berhubungan dengan Insidensi Preeklamsia}

\author{
Jesslyn M Sanusi, Hermie M M Tendean, Juneke J Kaeng \\ Department of Obstetrics and Gynecology \\ Faculty of Medicine Universitas Sam Ratulangi/ \\ Prof. Dr. R.D. Kandou Central General Hospital \\ Manado
}

\begin{abstract}
Objective: To determine the correlation between creatinine clearance relationship with preeclampsia incidence.

Method: We used cross-sectional study design.

Results: Creatinine clearance examination conducted on 60 sample of pregnant women $>20$ weeks, 30 normotensive samples and 30 preeclampsia samples. The obtained data analysed using SPSS software version 22.0 and discussed using the existing literature theory. Creatinine clearance average level in normotensive pregnancy $124.650 \pm 14.3699 \mathrm{ml} /$ minutes $/ 1.73 \mathrm{~m}^{2}$ and preeclampsia $74.003 \pm$ $23.169 \mathrm{ml} /$ minutes $/ 1.73 \mathrm{~m}^{2}$. After Mann-Whitney statistical test obtained $\mathrm{p}$ value $=0.000$. From ROC curve analysis for creatinine clearance obtained sensitivity value $100 \%$ and specificity $99.53 \%$.

Conclusion: There is a significant correlation between the creatinine clearance levels with preeclampsia.
\end{abstract}

[Indones J Obstet Gynecol 2018; 6-4: 213-217]

Keywords: creatinine clearance, normotensive, preeclampsia

\begin{abstract}
Abstrak
Tujuan: Menentukan hubungan antara creatinine clearance dengan kejadian preeklamsia.

Metode: Kami menggunakan desain studi potong lintang.

Hasil: Dilakukan pemeriksaan creatinine clearance pada 60 sampel ibu hamil> 20 minggu, 30 sampel darah normal dan 30 sampel preeklamsia. Data yang diperoleh dianalisa dengan menggunakan software SPSS versi 22.0 dan dibahas dengan menggunakan teori literatur yang ada. Kadar rerata creatinine clearance pada kehamilan nor-

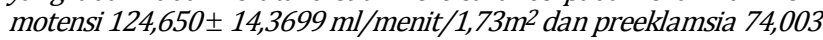
\pm 23,169 ml/menit/1,73m². Setelah uji statistik Mann-Whitney diperoleh nilai $p=0,000$. Dari analisis kurva ROC untuk creatinine clearance diperoleh nilai sensitivitas 100\% dan spesifisitas 99,53\%.

Kesimpulan: Ada hubungan yang signifikan antara creatinine clearance dengan kejadian preeklamsia.
\end{abstract}

[Maj Obstet Ginekol Indones 2018; 6-4: 213-217]

Kata kunci: creatinine clearance, normotensi, preeklamsia

Correspondence: Jessyln M Sanusi. jesslynmoysanusi@gmail.com

\section{INTRODUCTION}

Preeclampsia is a multiple organ disorder characterised by hypertension (blood pressure $\geq 140 / 90$ $\mathrm{mmHg}$ ) and proteinuria after 20 weeks of pregnancy. The clinical picture, preeclampsia occurs because the kidneys as the main target organ become endotheliosisglomerulus which led to a decrease in glomerular filtration rate. ${ }^{1-4}$

WHO estimates that preeclampsia cases seven times higher in developing countries than in developed countries. The preeclampsia prevalence in developed countries is $1.3 \%-6 \%$, while in developing countries is $1.8 \%-18 \%$. Preeclampsia is the second most common cause of maternal deaths in Indonesia after postpartum haemorrhage. ${ }^{5}$

The most often endothelial damage manifesta- tions organ in preeclampsia is kidney. Preeclampsia causes $75 \%$ of acute kidney failure in pregnancy. Kidney function is an essential component in the pathophysiology of preeclampsia so that close monitoring of kidney function is vital to ensure timely delivery before serious kidney damage occurs. ${ }^{1,2}$ Creatinine, urea, and uric acid are eliminated metabolite from the body through the kidney. Metabolite concentration measurement often used as kidney function indicator. ${ }^{6-9}$

Best calculation for glomerular filtration rate is by determining creatinine clearance. The creatinine cleanliness level in the blood plasma per unit, time used for filtration combination process and kidney glomerular secretion called creatinine clearance and a measure that can be observed from Glomerular Filtration Rate (GFR). ${ }^{10-11}$ 
Several studies have investigated the relationship of creatinine clearance with preeclampsia patients. Creatinine clearance in preeclamptic patients obtained significantly decreased compared with normotensive pregnancies. Creatinine clearance used to assess kidney glomerular function, it can be used as preeclampsia predictors. However, it still needs to be proven through studies. This is why the study was conducted.8,9

\section{OBJECTIVE}

To determine the correlation between creatinine clearance with the incidence of preeclampsia.

\section{METHODS}

We used cross-sectional study design to assess creatinine clearance relationship with the incidence of preeclampsia. Subjects were all pregnant women with normotensive and preeclampsia who went to the RSUP Prof. Dr. R. D. Kandou Manado and its affiliated hospital. Subjects consisted of two groups: 30 normotensive and 30 preeclampsia subjects. The inclusion criteria were 20 weeks' gestation women to term with preeclampsia, and willing to participate in research.
After anamnesis, physical examination, and signed informed consent, blood sampling performed. Serum creatinine levels in the blood sample examined in Laboratory RSUP Prof. Dr. R. D. Kandou Manado, then creatinine clearance calculated using the formula CKD-Epi $=141 \times \min$ $(\mathrm{S} c r / \mathrm{K}, 1)^{\alpha} \times \max (\mathrm{S} \text { cr } / \mathrm{K}, 1)^{-1.209} \times 0.993^{\text {Age }} \times$ 1.018 [if female] $\times 1.159$ [if black]. Scr: serum creatinine (mg/dl), K: 0.7 (for women) and 0.9 (for men), A: - 0.329 (for women) dan -0.411 (for men), Min: minimum of $\mathrm{Scr} /$ Kor 1, Max: maximum $\mathrm{fS}_{\mathrm{cr}}$ /Kor 1.

Data were analysed with the Mann-Whitney test to see whether there was relationship between creatinine clearance and preeclampsia. The data processed using Statistical Product and Service Solutions (SPSS) for Windows version 22.0.

\section{RESULTS}

A total of 60 subjects were recruited in this study. Subjects consisted of 30 normotensive and 30 preeclampsia subjects, all of which met the inclusion criteria and have signed the form of willingness to participate in this study. Characteristics of the subjects can be seen in Table 1 .

Table 1. Characteristics of the Subjects

\begin{tabular}{|c|c|c|c|c|}
\hline \multirow{2}{*}{ Characteristic } & \multicolumn{2}{|c|}{ Normotensive } & \multicolumn{2}{|c|}{ Preeclampsia } \\
\hline & $\mathbf{n}$ & $\%$ & $\mathbf{n}$ & $\%$ \\
\hline \multicolumn{5}{|l|}{ Age } \\
\hline$<35$ years & 24 & 80 & 16 & 53.33 \\
\hline$\geq 35$ years & 6 & 20 & 14 & 46.67 \\
\hline \multicolumn{5}{|l|}{ Parity } \\
\hline Primiparas & 15 & 50 & 13 & 43.33 \\
\hline Multiparas & 15 & 50 & 17 & 56.67 \\
\hline \multicolumn{5}{|l|}{ Gestational Age } \\
\hline$>20-28^{+6}$ weeks & - & 0 & - & 0 \\
\hline $29-36^{+6}$ weeks & 3 & 10 & 8 & 26.67 \\
\hline$>37$ weeks & 27 & 90 & 22 & 73.33 \\
\hline \multicolumn{5}{|l|}{ Highest Education } \\
\hline Bachelor (Sarjana) & 1 & 3.33 & - & 0 \\
\hline Senior High School (SLTA) & 13 & 43.33 & 14 & 46.67 \\
\hline Junior High School (SLTP) & 12 & 40 & 11 & 36.67 \\
\hline Elementary School (SD) & 4 & 13.33 & 5 & 16.67 \\
\hline \multicolumn{5}{|l|}{ Employment } \\
\hline Civil Servants & 1 & 3.33 & 1 & 3.33 \\
\hline Housewife & 29 & 96.67 & 29 & 96.67 \\
\hline
\end{tabular}


Table 2. The Creatinine Clearance of both Groups

\begin{tabular}{lccc}
\hline \hline Variable & $\begin{array}{c}\text { Normotensive } \\
\mathbf{n = 3 0}\end{array}$ & $\begin{array}{c}\text { Preeclampsia } \\
\mathbf{n = 3 0}\end{array}$ & $\mathbf{p}$ \\
\hline Creatinine clearance & & & \\
(ml/minutes $\left./ 1.73 \mathrm{~m}^{2}\right)$ & & & $<0.001$ \\
Mean \pm SD & $124.650 \pm 14.3699$ & $74.003 \pm 23.169$ & \\
Median & 124.600 & 76.850 & \\
Lowes Score & 79.9 & 17.4 & \\
Highest Score & 154.2 & 112.3 & \\
\hline
\end{tabular}

In this study, the normotensive group had higher mean creatinine clearance compared to the preeclampsia group $(124.650 \pm 14.3699$ vs 74.003 $\pm 23.169, \mathrm{p}<0.001$ ). The creatinine clearance of both groups is presented in Table 2 .

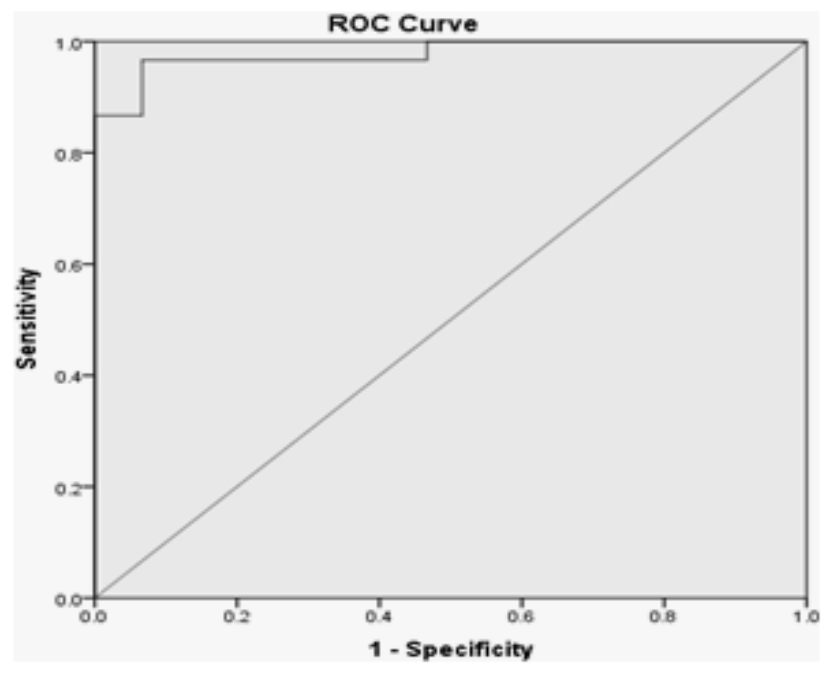

Figure 1. Graph of creatinine clearance variable distribution in preeclampsia and normotensive pregnancy group.

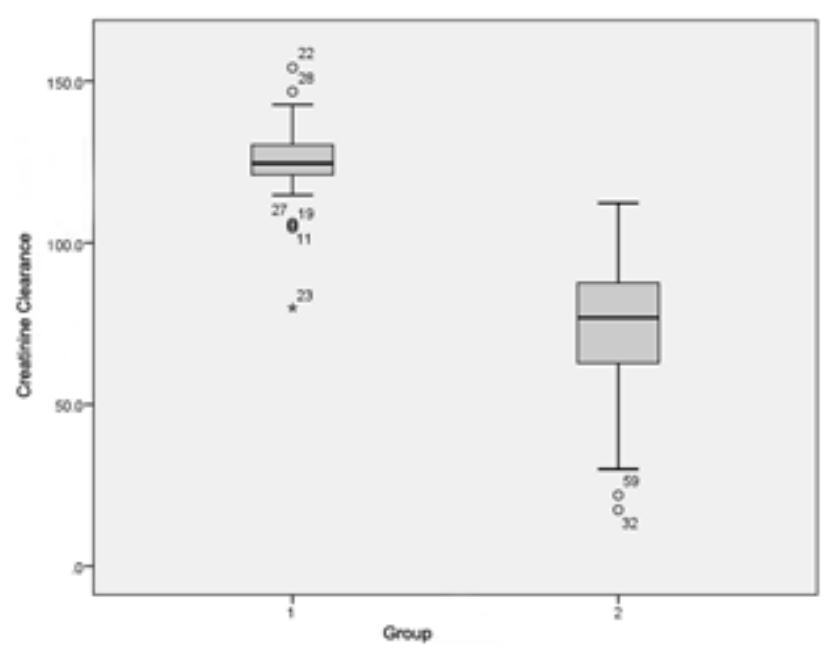

Figure 2. Graph of creatinine clearance ROC curve analysis.
ROC curve analysis creatinine clearance for normotensive patients, mild preeclampsia, and severe preeclampsia obtained the value of sensitivity $100 \%$ and specificity $99.53 \%$.

Mann-Whitney test conducted to determine the relationship between Creatinine Clearance with preeclampsia. Statistical test showed that $\mathrm{p}=$ 0.000 , which means that there is a significant relationship between creatinine clearance with preeclampsia.

\section{DISCUSSION}

This research aims to determine the existence of relationship between creatinine clearance with preeclampsia. This research on the relationship of creatinine clearance with preeclampsia is the first research conducted in RSUP Prof. Dr. R.D. Kandou Manado and network hospital.

Hypertension in pregnancy is one of the causes of maternal death. Preeclampsia is a secondary reduced perfusion organ pregnancy-specific syndrome to vasospasm and endothelial activation. Preeclampsia characterised by increased blood pressure accompanied by proteinuria in the pregnancy $>20$ weeks. Pathogenesis basis of preeclampsia is maternal endothelial cell damage. Hypertension and proteinuria that dominate the clinical picture occur because kidney as the primary target organ experiences morphologic change characterised by endotheliosis at kidney glomerulus that will inhibit the filtration process. Numerous researches have reported that kidney function decreases in pregnancy with preeclampsia. $1,2,12$

In Table 1 shows that by age in normotensive, the vast majority were $<35$ years as many as 24 peoples $(80 \%)$ and the least were age $\geq 35$ years as many as six peoples $(20 \%)$. Whereas in preeclampsia the vast majority were age $<35$ years as many as 16 people (53.33\%), followed by age $\geq 35$ years as many as 14 people (46.67\%). 
According to parity, in normotensive, normotensive as large as preeclampsia, i.e. 15 people (50\%). Whereas in preeclampsia, the vast majority were multiparas by 17 peoples (56.67\%) followed by primiparas 13 people (43.33).

Based on gestational age, in normotensive, the vast majority were in gestation $>37$ weeks by 27 peoples (90\%), followed by gestational age 29 $36^{+6}$ weeks by 3 peoples (10\%). Similarly, in a group of preeclampsia, the vast majority were in gestation > 37 weeks by 22 peoples $(73.33 \%)$, followed by gestational age $29-36^{+6}$ weeks by 8 peoples $(26.67 \%)$.

In the normotensive group, according to education characteristics, the vast majority were SLTA by 13 peoples (43.33\%), followed by SLTP 12 peoples (40\%), and SD 4 peoples (13.33\%), and the least bachelor was by one people only (3.33\%). Whereas in the preeclampsia group the vast majority were SLTA by 14 peoples (46.67\%), followed by SLTP 11 peoples (36.67\%), and SD 5 peoples $(16.67 \%)$.

According to the employment characteristics in the normotensive group, the vast majority were housewife by 29 peoples (96.67\%), followed by one civil servant $(3.33 \%)$. In the preeclampsia group, the vast majority were housewives by 29 peoples $(96.67 \%)$, followed by civil servant one people $(3.33 \%)$.

In Table 2, we could see that based on creatinine clearance in normotensive has mean value 124.650 , median value 124.600 , and standard deviation 14.3699. In preeclampsia has mean value 74.003 , median value 76.850 , and standard deviation 23.1699. Mann-Whitney test analysis obtains a $p$ value $=0.000$. A p-value less than 0.05 indicates that there are significant differences between normotensive and preeclampsia based on creatinine clearance. These results are also consistent with a study conducted by Israa Jumaahin 2012 where there was significant difference of creatinine clearance value in preeclampsia compared with normotensive. ${ }^{9}$

In this research, ROC curve analysis for creatinine clearance obtained sensitivity value $100 \%$ and specificity $99.53 \%$. Based on this sensitivity and specificity, showed that creatinine clearance is a good screening test for early detection of kidney disorder in patients with preeclampsia. Creatinine widely has been used to assess kidney function.
Creatinine clearance sufficiently sensitive in assessing changes in glomerular filtration rate in the early stages of kidney disorder. ${ }^{13}$

The results of this research support the previous research by other researchers. A study conducted by Reuters in 2015 stated that there were significant differences of creatinine clearance in preeclampsia when compared with normotensive pregnancies, whereas in normotensive case obtained creatinine clearance as much as 132.70 $\mathrm{ml} /$ minutes/1.73 $\mathrm{m}^{2}$ with standard deviation 11.0-15.6 and in preeclampsia $71.98 \mathrm{ml} /$ minutes/ $1.73 \mathrm{~m}^{2}$ with standard deviation $60-82.5$ and $\mathrm{p}$ value $<0.05 .12$

There is also research conducted by Israa Jumaah in 2012 performed on 100 pregnant women, where 50 were pregnant women with normotensive and 50 other pregnant women with preeclampsia. From those researches concluded that creatinine clearance in preeclampsia women $\left(103.6 \pm 29.63 \mathrm{ml} /\right.$ minutes $\left./ 1.73 \mathrm{~m}^{2}\right)$ significantly lower ( $\mathrm{p}<0.05$ ) compared with normotensive pregnant women $(125.30 \pm 15.14 \mathrm{ml} /$ minutes/ $\left.1.73 \mathrm{~m}^{2}\right) .{ }^{9}$

The decrease of creatinine clearance in preeclampsia patients was due to morphological changes in kidney characterised by endotheliosis that will inhibit glomerular filtration so that in preeclampsia reduced glomerular filtration rate will happen. Starting with placental ischemia as result of placental implantation disorder that will lead to the release of a number of placental material into the maternal circulation including an increase in sFlt-1 (soluble fms-like tyrosine kinase), pro-inflammatory cytokines (TNF $\alpha$ and IL6), AT1-AA (Angiotensin II type 1 Receptor Autoantibodies and Thromboxane). These factors contribute to the endothelial activation resulting in maternal endothelial disorder and produce clinical findings such as hypertension and proteinuria. Proteinuria and hypertension dominate the clinical picture because the main target organ is the kidney. Thus, changes in kidney function is an important component in the pathophysiology of preeclampsia. With the presence of endothelial dysfunction would lead to a decrease in kidney function, resulting in a decrease in glomerular filtration rate. ${ }^{14}$

In this research, there was significant relationship between preeclampsia and creatinine clearance. This supported by several previous studies, 
where creatinine clearance in preeclampsia significantly lower compared with normotensive pregnancies. Glomerular cell damage resulting increased in basement membrane permeability, thus lead to kidney filtration function disorder. ${ }^{2}$ Clinically reduced kidney perfusion, and glomerular filtration rate is very important. This situation will be growing along with the getting worse disease. With the decrease in glomerular filtration rate eventually, plasma creatinine levels increase which means that creatinine clearance decreases because of the kidney is less able to filter creatinine of the blood. 8,15

\section{CONCLUSION}

From this research, the mean of creatinine clearance in normotensive pregnancy group was $124.650 \mathrm{ml} /$ minutes $/ 1.73 \mathrm{~m}^{2}$, and preeclampsia $74.003 \mathrm{ml} /$ minutes $/ 1.73 \mathrm{~m}^{2}$. There was a significant relationship between creatinine clearance and preeclampsia. The mean rate of creatinine clearance in patients with preeclampsia was lower than normotensive.

\section{REFERENCES}

1. Cuningham FG. Pregnancy Hypertension in Williams Obstetrics. 24th ed. New York. McGraw-Hill. 2014: 706-49.

2. Miller DA. Hypertension in Pregnancy. In: Decherney AH, Nathan L, editors. Current Obstetric and Gynecology Diagnosis and Treatment. Tenth Edition. Philadelphia: McGraw Hill Companies, 2007: 318-24.
3. Wibowo N, Irwinda R. Pedoman Nasional Pelayanan Kedokteran: Diagnosis dan Tata Laksana Preeklamsia. Kementrian Kesehatan Republik Indonesia. 2014.

4. Himpunan Kedokteran Feto Maternal POGI. Penatalaksanaan Hipertensi dalam Kehamilan. HKFM. 2010.

5. Supriyantoro, Primadi O. Profil Kesehatan Indonesia Tahun 2013. Kementerian Kesehatan Republik Indonesia. 2014: 71-83.

6. Al-Jameil N. Identification of Predictive Marker of Pre-Renal Damage in Pregnant Women with Preeclampsia and Women At High Risk - A Prospective Study Conducted in Riyadh, Saudi Arabia. Int J Med Sci Public Health. 2014: 18690.

7. Mustafa R. A Comprehensive Review of Hypertension in Pregnancy. J Preg. 2012: 1-23.

8. Sonagara AD. Evaluation of Glomerular Function in Women with Preeclampsia. Ejpmr. 2015; 2(2): 288-95.

9. Jumaah IAM. Estimation of Uric Acid, Urea, Creatinine, and Creatinine Clearance in the Serum of Preeclampsia Women. Kerbala J Pharma Sci, 2012; 4: 183-9.

10. Creasy R. Creasy and Resnik's Maternal-Fetal Medicine $6^{\text {th }}$ ed. Philadelphia: Elsevier Saunders. 2012: 651-67.

11. Setiati S. Ilmu Penyakit Dalam Ed 6 Jilid II. Perhimpunan Dokter Penyakit Dalam Indonesia. Jakarta: Interna Publishing. 2014: 2050-2.

12. Reuters T. Creatinine Clearance as Marker for Diagnosing the Severity of Preeclampsia. India. Int J Pharma Scien Research. 2015; 4: 1488-94.

13. Meads C.A. Methods of Prediction and Prevention of Preeclampsia: Systematic reviews of Accuracy and Effectiveness Literature with Economic Modelling: Health Technol Asses. 2008; 12(6): iii-iv, 1-270.

14. Fadel H.E. Creatinine Clearance Rate in Preeclampsia and Eclampsia. Am College Obstet Gynecol. 2000; 32(5): 636-6.

15. Manjareeka M. Elevated Levels of Serum Uric Acid, Creatinine, or Urea in Preeclampsia Women. Int J Med Sci Public Health. 2013; 2: 43-7. 